Dicle University Journal of Engineering (DUJE)

web: http://dergipark.gov.tr/dumf

Derleme Makalesi / Review Article

\title{
Ulusal, Bölgesel ve Uluslararası Bazda Yüksek Hızlı Demiryollarının Gelişimi, Mevcut Durumu ve Yatırım Planlarına Dair Bir Derleme
}

\section{Comparative Evaluation Of Development, Existing Case and Investment Plans on High Speed Railways in National, Regional and International Scale}

\author{
Mehmet Fatih Altan ${ }^{*}$, Mehmet Çağrı Kızıltaş² \\ ${ }^{1}$ İstanbul Aydın Üniversitesi, İnşaat Mühendisliği Bölümü, İstanbul, mehmetaltan@aydin.edu.tr \\ ${ }^{2}$ İstanbul Ticaret Üniversitesi, İnşaat Mühendisliği Bölümü, İstanbul, mckiziltas@ticaret.edu.tr
}

\begin{tabular}{|c|c|}
\hline MAKALE BİLGİLERİ & ÖZET \\
\hline & \multirow{6}{*}{$\begin{array}{l}\text { Günümüzde kimi çalışmalarda demiryolu sistemi üzerine yoğunlaşmak yerine otomobil ve havayolu ulaştırma } \\
\text { türlerinin geliştirilmesi ile ilgilenilmektedir. Fakat kullanıc davranışları ele alındığında bir yolculuk tercihinde } \\
\text { sadece teknik imkânlar değil aynı zamanda sosyal eğilimlerinin de etkili olduğu görülecektir. Eğer sosyal } \\
\text { dinamiklerin demiryolu ulaştırmasının gelişimine adaptasyonu söz konusu olursa yüksek hızlı demiryollar } \\
\text { modern ulaştırma sisteminde öncül bir konuma gelebilir. Bu yönde çalışmalara odaklanılması için fazlası ile } \\
\text { gerekçe bulunmaktadır. Çelik tekerlekli demiryolları etkili ve doğrudan bir hizmet sunmaktadır. Yüksek hızl } \\
\text { demiryollarının getirdiği teknik kolaylıklar dünya çapında tanınmış ve onaylanmış durumdadır. Bunun yanı sıra } \\
\text { önemli bir kısmı yüksek hızlı demiryollarına entegre edilebilecek olan çok ciddi miktardaki bir konvansiyone } \\
\text { demiryolu hattı da halihazırda bulunmaktadır. Demiryolu ulaştırması aynı zamanda enerji etkin ve çevre dostudur. } \\
\text { Yüksek hızlı demiryolları araç, altyapı ve tren gibi unsurlar bakımından kayda değer bir gelişim kat etmiş } \\
\text { olduğundan günümüzde daha çok ağın stratejik gelişimi ve hizmet parametreleri gibi unsurlara eğilinmektedir. Bu } \\
\text { çalışma kapsamında yüksek hızlı demiryollarının yatırım maliyetleri değerlendirilmiştir. Bu bağlamda Japonya } \\
\text { ana örnek olarak ele alındıktan sonra Birleşik Krallık ve Almanya'da bu sistemdeki mevcut durum detaylı olarak } \\
\text { incelenmiş ve çeşitli karşılaştırmalar yapılmıştır. Bu bağlamda küresel derlemeler dâhilinde sonuçlar ortaya } \\
\text { konmustur. }\end{array}$} \\
\hline Geliș: 4 Ağustos 2018 & \\
\hline Düzeltme: 22 Aralık 2018 & \\
\hline Kabul: 13 Şubat 2019 & \\
\hline Anahtar kelimeler: & \\
\hline $\begin{array}{l}\text { Altyapı, işletme, türel dağılım, } \\
\text { karşılaştırmalı değerlendirme, } \\
\text { yüksek hızlı demiryolları }\end{array}$ & \\
\hline
\end{tabular}

Doi: $10.24012 /$ dumf. 450985

\begin{tabular}{|c|c|}
\hline ARTICLE INFO & ABSTRACT \\
\hline Article history: & \multirow{6}{*}{$\begin{array}{l}\text { Transport, from the existence of mankind to today; the causes and consequences of social relations and technical } \\
\text { developments constitute one of the main elements of an integrated system. It is therefore at the center of all social, } \\
\text { economic, technical, cultural and political processes as a driving force. Transportation, which is inextricably linked } \\
\text { to urbanization and has a reciprocal relationship, will only be able to provide 'inputs and outputs' in a coherent and } \\
\text { integrated systematic approach. One of the most important dilemmas of our country for many decades has been } \\
\text { the fact that every arena approach and non-integrative actions and thoughts are taking place. From this point of } \\
\text { view, our basic need for an integrated approach is in many respects, especially in academy, market, urbanization } \\
\text { and transportation, theory and practice. We live in similar issues, such as 'integration between modes, human- } \\
\text { focused approach, balanced distribution, upgrading of service parameters' which are the main subjects of } \\
\text { transportation.On this context firstly the general concept of HSR is evaluated, then Germany and United Kingdom } \\
\text { system samples are revealed for a focused discussion. After these, a detailed comparison has done by means of } \\
\text { USA and EU transportation data. Lastly investment costs are analysed generally. As a result conclusions and } \\
\text { recommendations are given on a continental scale. }\end{array}$} \\
\hline Received: 4 August 2018 & \\
\hline Revised: 22 December 2018 & \\
\hline Accepted: 13 February 2019 & \\
\hline Keywords: & \\
\hline $\begin{array}{l}\text { Operation, modal distribution, } \\
\text { high speed railways }\end{array}$ & \\
\hline
\end{tabular}

* Sorumlu yazar / Correspondence

Mehmet Fatih ALTAN

$\bowtie$ mehmetaltan@aydin.edu.tr 


\section{Giriș}

Yüksek hızlı demiryollarının (YHD) Avrupa'da sürekli bir büyüme gösterdiği görülmektedir. Söz konusu ilerleme periyodu; ülkelerdeki yenilikçi yaklaşımlar, demiryolu teknolojileri, kentsel şekillenmeler, politik çeşitlilik ve merkezden uzaklaşma süreçlerine göre değişimler göstermektedir. Kesin ve net tablolarla bu sektörde tanımlara sahip iki ülke olarak ise İspanya ve Fransa zikredilebilir. Söz konusu karakteristikler; merkezi yerlerin merkezi karakterini güçlendiren ve büyük mesafe aralıklarında az durak sayılarını içeren şekillerle ifade edilebilir. Ayrıca söz konusu iki ülkenin ana amaçlarından birisi de başkentleri Madrid ve Paris'i ana kent mekânları olmaları hasebi ile birbirilerine bağlamaktır. Bu minvalde yüksek hızlı demiryollarında (YHD) daha değişik tasniflerden söz etmek de mümkündür.

Söz konusu tasnifler bağlamında hat üzerindeki arada kalan kentlerin YHD güzergâhı boyunca ana istasyonlardaki büyük kentlere olan mesafelerine ve büyüklük hacimlerine göre değerlendirildiği görülmektedir. YHD'nın bilimsel değerlendirmesi; belirli bir zaman aralığında konvansiyonel anlayışa göre kentsel, bölgesel ve ulusal ölçekte konum bazlı olarak gerçekleştirilmektedir.

Mesela bir ölçek olarak üretilen yolculuk maliyetinden, potansiyel erişilebilirlikte faydalanılabilmektedir. Bunun yanında da bir erişilebilirlik öngörü unsuru olarak da yolculuk süresi fiyat ve sefer frekansı paralelinde kullanılabilmektedir. Ayrıca Fransa'daki çoğu YHD eksperi temel bir kıstas olarak yolculuk süresini almaktadır. Yolculuk süresi, ulaştırma türü eksenli olarak yüksek hılı demiryolu (YHD)-havayolu yolcu taşımacılığı (HYT) rekabetinin ölçütlerinde orta büyüklükteki kentler arasında en önemli belirleyici unsurlardan birisi olmaktadır.

Mücavir alandaki taşımacılık ağlarına yakınlık; kentlerin yerleşim pozisyonları açısından, belli başlı merkezlere yakınlıktan daha önemli bir role sahip olmaktadır. Söz konusu açıdan bakılacak olur ise milli ölçekte orta büyüklükteki kentler için iki aşamadan bahsedilebilir.

Bunlardan birincisi; YHD ulaştırmasının mücavir alandaki büyük kentler ile bağlantısı iken ikincisi ise mücavir alanlardaki büyük kentlerden YHD sayesinde akan yolcunun söz konusu kentlere de uğramasının sağlanmasıdır [1].

Türkiye'de ise yüksek hızlı demiryolları (YHD) hızlı bir gelişim süreci içerisindedir. İlk olarak Ankara-Eskişehir YHD hattı tamamlanmış olup ardından Ankara-Konya YHD hattı işletime alınmıştır. Akabinde Eskişehir-Konya YHD hat bağlantısı hayata geçirilmiş olup akabinde ise Eskişehir-İstanbul YHD hat etabı tamamlanarak Ankara-Eskișehir-İstanbul YHD hattı tam kapasite işletime başlamıştır. Aşağıda Tablo 1'de Türkiye'de işletimdeki ve inşa halindeki YHD tabloları görülmektedir.

Tablo 1.Türkiye'deki YHD Hatlarının Durumu [2]

Türkiye’deki YHD Hatları

\begin{tabular}{c|c}
\hline Ankara-Eskişehir-İstanbul & İşletimde \\
\hline Ankara-Konya & İşletimde \\
\hline Eskişehir-Konya & İşletimde \\
\hline Ankara-Yozgat-Sivas & Yapımda \\
\hline Ankara-Afyon-Manisa-İzmir & Yapımda \\
\hline Eskişehir-Bursa-Bandırma & Yapımda \\
\hline
\end{tabular}

Aşağıda Şekil 1'de ise Türkiye'deki mevcut demiryolu ağı haritası verilmiştir.

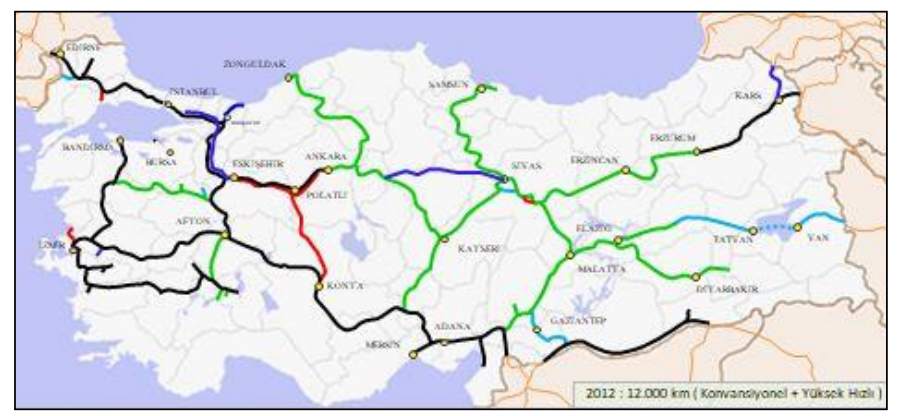

Şekil 1. Yüksek Hızlı Demiryollarından önce Madrid-Sevilya arası türel dă̆ılım [3]

Türkiye yüksek hızlı demiryollarında (YHD) yatırımlara 2002 yılı itibari ile başlamış ve hızlı bir yol almıştır. Konan hat kilometre hedeflerine bugüne kadar büyük ölçüde ulaşılmış olup bundan sonra da ulaşmak söz konusu olabilir. 
Zira Ankara-Yozgat-Sivas YHD hattının 2020 yılı itibari ile açılması beklenebilir. AnkaraAfyon-Manisa-İzmir YHD hattının inşası da hizla devam etmekte olup hattın yarıs1 tamamlanmış bir vaziyettedir [4]. Bununla beraber İstanbul-Edirne YHD hattının inşasına başlama sürecine girmiştir. Ülkemizde ikinci bir Ankara-İstanbul YHD hattı düşünülmekte olup bu hattın Bolu üzerinden geçmesi planlanmaktadır. Dolayısı ile bu söz konusu hat kilometre uzunluğu olarak hâlihazırdaki hattan daha kısa olacak olup daha üst düzey bir altyapı üzerinde olmasi nedeni ile de 300-350 $\mathrm{km} / \mathrm{saat}$ 'lik işletim hızlarına ulaşabilecektir. $\mathrm{Bu}$ durumda iki kent arasındaki YHD seyahat süresi 60-90 dakikalık zaman dilimlerine kadar inebilecektir. Ülkemiz günümüz itibari ile hat kilometreleri de göz önünde bulundurulduğunda küresel ölçekte, YHD sektöründe Japonya, Fransa, Çin, İspanya ve Almanya'dan sonra 6.sirada zikredilebilir bir durumdadır [4].

\section{Materyal ve Yöntem}

Gelişmiş ülkelerde yıllık altyapı yatırım bütçelerinin toplam bütçeden aldığı pay azdır. Zira bu ülkeler gelişmiş seviyeye geldiklerinden kısmi sorunlar ve periyodik harcamalar dışında büyük altyap1 projelerine girişmemekte ve dolayısı ile de altyapıya büyük harcamalar yapmamaktadırlar. Gelişmekte olan ülkeler ise henüz gelişim periyodunda olduklarından dolayı altyap 1 bu ülkelerde hem etkileyen (tetikleyen, besleyen) ve hem de etkilenen bir parametre olarak stratejik bir noktadadır [5]. Zira ekonomik kalkınma sağlam bir temel üzerine inşa edilebilir. $\mathrm{Bu}$ temel de altyapıdır. Gelişmekte olan ülkelerde yoğun bir altyapı kurulumu sürecinden söz edilebilir. Buradan hareketle gelişmekte olan ülkelerde yıllık bütçede altyapı yatırımlarının aldığı paylar oldukça yüksek olmaktadır. Gelişmemiş ülkelerde ise henüz ekonomik ivmelenme kazanılamadığı için ne yeterli ölçüde altyapıya olan gereksinim ivmelenmiş ve ne de altyapı kurulumu için itici güç temin edilebilmiştir. Dolayısı ile bu ülkeler henüz altyapı öncesi kurulum aşamasında bulunmaktadırlar. Buradan hareketle de bu ülkelerin y1llık bütçelerinde altyapı yatırımlarının aldığı pay daha sınırlı olmaktadır.
Yüksek hızlı demiryollarının (YHD) ilk ortaya çıkış 50 yıl önce Japonya'da Shinkansen trenleri ile olmuştur. Ardından Fransa'da TGV öncülüğünde ortaya çıkan ve ilerleyen bir yüksek hizlı demiryolu (YHD) sürecinden bahsedilebilir. Takibinde de Almanya'da ICE trenleri ile bir yüksek hızlı demiryolu (YHD) sektörü ve sistemi ortaya çıkmıştır. Uzun yıllar küresel ölçekte sektörün öncülüğü Japonya, Fransa ve Almanya' da olmuş olup aynı dönemde İtalya, Birleşik Krallık, İsveç ve benzeri ülkelerde bu ulaştırma türünde gelişimler kaydedilmiştir. Akabinde ise son on yılda İspanya ve Çin yüksek hızlı demiryollarına (YHD) hızlı bir giriş yapmış olup sektörün liderleri arasındaki yerlerini almıştır. Ülkemizin yüksek hızlı demiryollarına (YHD) giriş ve ilerleyişi de yine bu dönemdedir. İspanya'nın yüksek hızlı demiryolu (YHD) şirketi AVE iken Çin'inki ise CRRC'dir. Bu kurum adlandırmalarının hemen hepsi kendi ülke dillerinde yüksek hızlı tren anlamına gelmektedir. Günümüz itibari ile yüksek hızlı demiryolu (YHD) sisteminin öncüleri Japonya, Fransa, Çin ve İspanya'dır.

\section{Büyük Britanya}

Eurostar trenleri Belçika, Fransa ve İngiltere arasındaki Eurotunnel boyunca işletilmekte olup değişen güç operasyonları ile yedi çeşit sinyalizasyon aksamı ile çalışabilmektedir. $\mathrm{Bu}$ trenler TGV trenlerinin ileri bir çeşididir. Her bir trende 18 tane yolcu vagonu bulunmaktadir. $\mathrm{Bu}$ nedenle de Avrupa kentleri ile Londra arasında ciddi bir yolcu taşımacılığı hacmine sahip olduğu söylenebilmektedir. Birkaç büyük uçağın karşılığ edilebilmektedir. Kanal Tüneli (Channel Tunnel) yolu ile trenlerin İngiliz kanalını aştığından bahsedilebilir. Londra'nın Paris ve Brüksel ile bağlantısını sağlayan trenler Eurostar trenleridir. Eurotunnel aynı zamanda münhasıran bir şirket olarak teşekkül etmiş olup Kanal Tünelinin inşa ve işletimcisi konumundadır. Eurostar TGV ve Thalys ile aynı yüksek hızlı demiryolu hatlarından faydalanmakta olup yeniden gelişim periyodu paralelinde yeni bir hat yapımı da İngiltere'de söz konusu olmaktadır. Bu bahsi geçen süreç iki aşamalı olarak şekillenen ve 
CTRL olarak bilinen Kanal Tünelindeki demiryolu bağlantısı projesidir [6].

$200 \mathrm{~km} / \mathrm{saat}$ işletim hızı ile Great Western Main Line'da (büyük batı ana hat) ile East Coast Main Line'da (doğu yaka ana hattı) 1976 yılından itibaren yüksek hızlı tren seferleri yapıldığı görülmektedir. Bu söz konusu hatlar Britanya' da demiryollarının yolcu taşımacılığında 20 yıldan fazla bir süredir de ana gövde konumunu almış bulunmaktadır. 10 yıllık periyotlu Ulaştırma 2010 planı ise 2000 yılında Çevre Taşımacılık ve Bölgeselleşme Bakanlığı (DETR) tarafından oluşturulmuş olup modernizasyon ve işletim ile ilgili çeşitli göndermelerde bulunur iken diğer taraftan ise yeni bir yüksek hızlı tren hat yapımı ile ilgili ise herhangi bir yaklaşım geliştirilmemektedir. Söz konusu göndermeler ise CTRL hattının bitirilmesi, hâlihazırdaki hatlarda zaman tasarruflarını arttıran ilerlemeler ve WCML başta olmak üzere hâlihazırdaki güzergâhlarda hatların modernizasyonu noktalarını içermektedir. Esasen çoğu zaman temel koridorlarda hâlihazır güzergâh altyapılarının ilerletilmesi noktası Britanya'daki demiryolu ulaştırması stratejisince desteklenmektedir. 2006 y1lında mevcut hat uzunluklarının Britanya için yeterli olduğu görüşü Eddington Transport Study (ulaştırma çalışmaları birimi) tarafından, Fransa ve İspanya'daki kent merkezlerine nazaran birbirine daha kısa mesafelerde bağlandığ 1 hareket noktası nazarı ile savunulmuştur. Eddington Transport Study, projeler büyüdükçe geri kazanım oranlarını muğlâklaşabildiğini ve bu sebep ile de yoğun güzergâhlarda yoğunluğun düşürülmesinde en önemli mali alternatifin yüksek hızlı trenlerin olduğunu ileri sürmüştür. Britanya idaresi tarafindan yayınlanan Beyaz Kitap da söz konusu savunmayı desteklemektedir.

\section{Almanya}

İngiltere'de ve birçok yerde olduğu şekli ile Almanya'da da yüksek hızlı tren hızları, demiryolu özellikleri ve altyapı nitelikleri ile limitlidir. Yolcu ve yük taşımacılıklarının ana koridorda beraber gerçekleştirildiği bir sistem söz konusu olmaktadır. 1980'li y1llarda Fransa' dakinin akabinde Almanya'da da yüksek hızlı demiryolu (YHD) sektörüne giriş gerçekleşmiştir. Almanya'nın tamamına yayılmış olan InterCity Express (Şehirlerarası Ekspres-ICE) düzenli ve sürekli olarak yüksek hızlarda ișletimi gerçekleştirmektedir. Ülkede $290 \mathrm{~km} / \mathrm{saat}$ hız limitini aşan sadece iki hat bulunmaktadır, buna karşın ülkenin Avrupa'nın en büyük ekonomisi olduğunu hatırlamakta da yarar vardır. Söz konusu iki hat ise sıras1 ile Münih-Nuremburg ve Köln-Frankfurt'tur. Almanya'daki diğer pek çok hat ise $200 \mathrm{~km} / \mathrm{saat}$ 'lik işletim hızlarına haiz olmaktadır [6]. Bütün bunlar ise Fransa'daki TGV'ye nazaran düşük işletim hızlarına erişildiğine işaret etmektedir. Fransa'da TGV, Paris ve Marsilya arasinı 3 saatte kat etmekte iken aynı mesafelerdeki Münih-Berlin seyahat süresi ise 6 saat olarak gerçekleşmektedir. Almanya'nın yüksek hızlı demiryolları tecrübesi köklü olup, bu konuda uzun süre Avrupa ve dünya lideri konumunda olmuştur. Fakat bununla birlikte son y1llarda bu ivmelenmesini İspanya'ya kaptırdığı görülmektedir. Şekil 2'de İspanya'nın Madrid ve Sevilya şehirleri arasında yüksek hızlı trenden önceki türel dağılım görülmektedir. $\mathrm{Bu}$ tablonun sebepleri, aynı konfor parametrelerini ve hız değerlerindeki gelişmeleri sürdürmeyi başaramamış olması ve önemli bazı facia niteliğinde YHD Kazalarına ev sahipliği yapmış olmasidır. Almanya'da ICE (InterCity Express) yüksek hizlı tren hizmetini sunmakta olup, şehirlerarası yüksek hız olarak tercüme edilebilir. Ülke içinde hatlar daha ziyade Kuzey-Güney eksenli olup yer yer Doğu-Batı eksenli hatlarda mevcuttur. Ülke içinde ise ana servis güzergâhları Berlin-MünihHamburg-Köln ve Frankfurt merkezlidir.

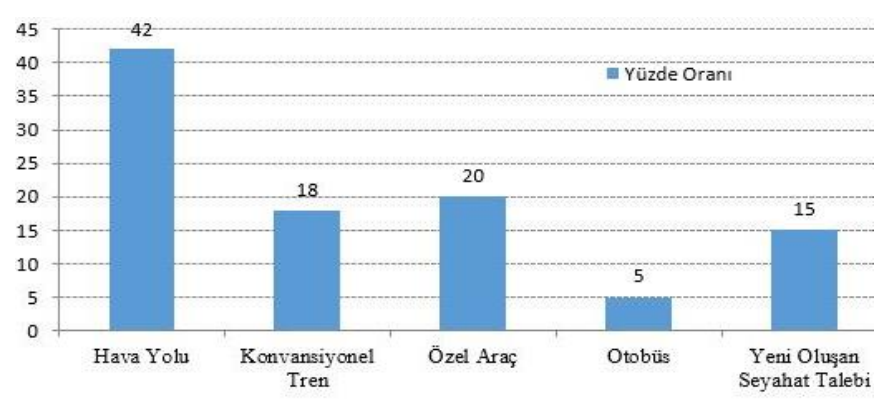

Şekil 2. Yüksek Hizlı Demiryollarından önce Madrid-Sevilya arası türel dăğlım [7] Almanya, hiz rekorları kirılması konusunda Fransa ile rekabet halinde olup 1986'da 346 $\mathrm{km} / \mathrm{saat}$ ve $1988^{\prime} \mathrm{de} 407 \mathrm{~km} / \mathrm{saat}$ lik hiz değerlerine ulaşmıştır fakat periyodik hizmetleri genellikle konvansiyonel raylar üzerinde Britanya Demiryolları süratlerinde takip etmektedir. Tepelik arazi yapıları ve düşük 
eğimli kesitlerden geçme ihtiyacı yük taşımacılığının yeni altyapılar kullanması ve mukayeseli olarak yapım maliyetlerinin yükselmesi sonucunu doğurmuştur. Ayrıca, masraflar Alman kamuoyunun yüksek çevre algısı ve hassasiyetinden etkilenmiş olup bu, daha karmaşık ve âdemi merkeziyetçi bir politik atmosfer oluşturmuştur. Bütün bunlar, yapım maliyetlerinin kaçınılmaz olarak kilometre başına neredeyse TGV'ninkinin üç katı olması anlamına gelmekteydi. Aynı zamanda, ICE'nin daha sınırlı etkilerine bağlı olarak TGV ve Shinkansen'e kıyasla trafik çekimleri de daha düşüktür [7].

ICE trenleri yeni yapılan bölümlerde 250 $\mathrm{km} /$ saat'lik maksimum hıza ulaşmaktadırlar. Berlin-Hannover arasındaki yüksek hızlı tren hattı 1998'de açılmış ve Ağustos 2002'de 177 km'lik önemli bir hat olan Köln-Rhine/Main yeni hattında seferler başlatılmıştır. Hâlihazırda yapım aşamasında olan diğer hatlar NurnbergIngolstadt, Karlsruhe-Offenburg ve KölnAachen yollarıdır. ICE 2.000 km'lik bir ağa sahiptir. Bu ağın sadece yarısı $250 \mathrm{~km} /$ saat'ten daha fazla hıza imkân tanımaktadır. ICE yalnızca 1991 yılında işletilmeye başlamasına rağmen o zamandan beri büyük gelişmeler kaydetmiştir. İlk trenler iki lokomotife ve 723 oturma kapasitesine sahip azami 14 yolcu vagonuna sahiptiler. Yeni geliştirilen ICE 2,2, $8.000 \mathrm{~kW}$ 'l1k bir performansa sahiptir ve maksimum $330 \mathrm{~km} /$ saat hıza ulaşmaktadır. Bu yeni trenlerin dizaynındaki yenilik, ağırlığı eşit dağıtan ve daha fazla hızlanmayı sağlayan sürüş biriminin her vagonda yer [7].

$\mathrm{Bu}$ trenlerden bazıları uluslararası seferler için değişik güç sistemlerini kullanabilecek şekilde imal edilmiştir. ICE Servisleri; ülke içi entegrasyonun yanı sira Kopenhag (Danimarka), Zürih (İsviçre), Londra (İngiltere), Paris (Fransa), Viyana (Avusturya), Amsterdam (Hollanda) ve Brüksel (Belçika) servisleri ile de geniş bir $\mathrm{AB}$ Entegrasyon alanı oluşturmuştur. Almanya'da yüksek hızlı demiryolu hizmeti Haziran 1991'de ICE'nin (Şehirlerarası Ekspres) pazara girmesi ve Hamburg ve Münih'i birbirine bağlayan iki hattın açılmasıyla başlamıştır. Almanya devlet demiryolları DeutscheBahn'ın yarı bağımsız şirketi DB Fernverkehr tarafından işletilmektedir.

\section{Küresel Karşılaștırmalar}

Amerika Birleşik Devletleri'ne kıyasla yakıt fiyatlarının daha yüksek olduğu Avrupa Birliği'nde otoyol ücretlendirme uygulamaları daha fazla görülmektedir. Geneli itibari ile yakıt fiyatları Avrupa Birliği'nde Amerika Birleşik Devletleri'ndekinin iki katı olmakla beraber coğrafi bölgeler ve zaman periyotlarına göre değişim göstermektedir. Otoyol ücretlendirmeleri Amerika Birleşik Devletleri'ndeki yolların \%1,3'ü nispetinde iken bu oran Avrupa Birliği’ndeki ülkelerde kilometre bazlı olarak \%12 ila \%30 nispetlerindedir [8]. Yüksek hızlı demiryolu hatlarına göre değişen türel oranlar ve yolculuk zamanları Şekil 3'de gösterilmektedir [9]. Aynı zamanda Avrupa Birliği'nde Amerika Birleşik Devletleri'ne (ABD) nazaran demiryolu ulaştırma türü sübvansiyon uygulama süreci daha yavaştır. Diğer taraftan ise Amerika Birleşik Devletleri'nde demiryolu ulaştırma türü yük taşımacılığında sübvansiyon konusu gelir vergilerinin doğrudan olmayan yöntemler ile eyaletler ve ilgili kuruluşlar vasitası ile gerçekleştiği (2001 yılı itibari ile 538 milyon ABD Doları) görülmekte iken yolcu taşımacılığında ise ciddi oranlarda doğrudan sübvanse söz konusu olmaktadır.

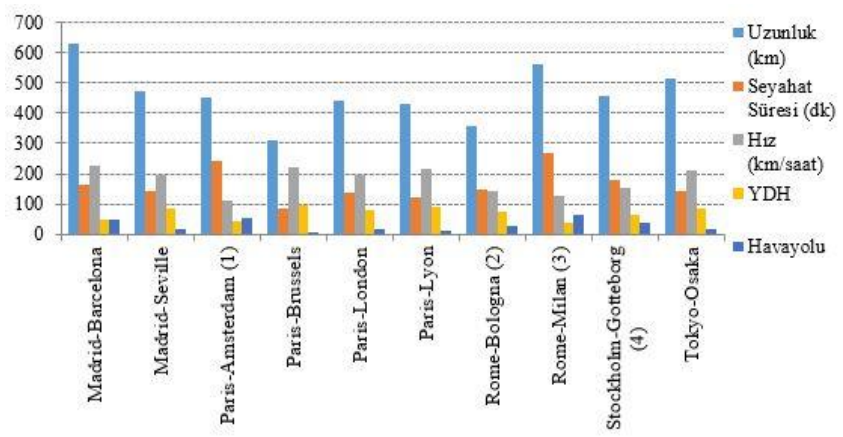

Şekil 3. Çeşitli Yüksek Hızlı Demiryolu hatlarında seyahat süreleri ve türel payları [9]

Genel olarak Avrupa Birliği'nde (AB) sübvansiyonların yarısından fazlası demiryolu ulaştırma türü yolcu taşımacılığına aktarılmakta olup söz konusu oranların yaklaşık yarısı yolcu ve yük taşımacılığının beraber yapıldığı hatlara yönlendirilmektedir (2001 y1lı itibari ile 38,306 milyon Euro'nun 18,364 milyon Euro'luk bölümü). Demiryolu yolcu ulaştırmasının demiryolu yük 
ulaştırmasından çok daha fazla öncelemesi, Avrupa Birliği (AB) demiryolu politikalarının olumsuz yönlerinden birisi olarak değerlendirilmekte olup bu bağlamda kentler arası yolcu ulaştırmasında demiryolunun paylarına göz atıldığında, Amerika Birleşik Devletleri'nde (ABD) bunun yalnızca \%0,32 iken Avrupa Birliği'nde (AB) ise $\% 6,25$ olduğu göze çarpmaktadır [8]. Demiryolları karayolu ulaştırma türünün dengesiz ağırlığını dengeleyebilecek en önemli etkenlerin başında gelmektedir. Çünkü dengeli türel dağılımın ve türler arası entegrasyonun sağlanmasında demiryollarının birçok farklı etkinliği ve işlevi söz konusu olabilmektedir. Karayolu ulaştırma türündeki dengesiz ağırlık sadece diğer ulaştırma türlerinin aleyhine olan basit bir karşıllklı rekabet ilişkisine işaret etmemektedir. $\mathrm{Bu}$ durum bunun daha da ötesinde hem toplam ulaştırma sisteminin ve hem de karayolu ulaştırma türünün bizatihi kendisinin aleyhine bir durumdur [10]. Zira kapasitesinin üzerindeki bir yükleme, karayolu ulaştırma türünü işlevlerini aksatır ve yerine getiremez hale getirmektedir. Bunun en önemli çıktısı ise karayolu trafik güvenliği hususunda kendisini göstermektedir. Öyle ki ülkemiz halen Avrupa Birliği (AB) ülkelerine kıyasla, bütün bu ülkelerin toplamı ile karşılaştırılabilecek ölçeklerde yıllık trafik kazası ve yıllık trafik kaza kayıpları verilerine sahiptir. $\mathrm{Bu}$ da başlı başına ciddi sayıda (savaş, terör vs. ile kıyaslanabilecek kadar) insan kaybına ve önemli milli varlık kayıplarına işaret etmektedir. Dengesiz türel yüklemenin daha birçok zararından da bahsedilebilir. Şu da unutulmamalıdır ki ulaştırma türleri arasındaki yegâne bağıntı, rekabet yönünde olmayıp bunun yanı sira birbirini tamamlama, birbiri yerine ikame, entegrasyon gibi birçok işlevleri vardır. $A B$ ve ABD'nin demiryolu ağı uzunluklarına bakıldığında birbirlerine oldukça yakın kilometreler olduğu görülmekte olup bu değerler $\mathrm{AB}$ için 215.000 kilometre iken ABD için ise 203.600 kilometredir [11]. Bununla birlikte Avrupa Birliği'nde yük taşımacılığında taşıma periyotları uzamakta ve trafik kaynaklı problemlere bağlı olarak da büyük gecikmeler yaşanabilmektedir. Bunun nedenleri ise sırası ile sürekli bir ulaştırmanın tam anlamı ile temin edilememesi (ulusal sinırlar, ulusal kaynaklı kurumsal ve teknolojik değişiklikler), altyapı bazlı olarak yük ve yolcu taşımacılığı ortaklaşmalarının daha fazla olması, yük taşımacılığı hızlarının nispeten daha düşük gerçekleşmesi ve yolcu taşımacılığında geçiş önceliğinin bulunması olarak özetlenebilir. Çeşitli çalışmalarda ifade edildiği üzere Amerika
Birleşik Devletleri'nde ton/kilometre maliyeti yaklaşık 1 sent iken Avrupa Birliği'nde ise bu oran 8 sent dolaylarındadır. Avrupa Birliği'nde demiryolu ulaştırması yük taşımacılık güzergâhlarının meydana getirilmesine; 913/2010 say1lı çerçeve ile girişilmiş olup 2015 y1lına kadar da üye ülkelere ilgili işleri bitirme mecburiyeti getirilmiştir. Bunun arkasında ise yük ulaştırmasının, çeşitli hatların yük ulaştırmasına ayrılması yolu ile güçlenmesi konusu bulunmaktadır [12].

\section{Yatırım Maliyeti}

Kilometre başına maliyet, 4 milyon ABD Doları olarak konmuş ve halen en pahalı Fransız yatırımları 10-15 milyon ABD Dolarları seviyesinde gerçekleşiyor olup bu, İtalya'nın 25 milyon ABD Doları/km ve Birleşik Krallık'1n 74 milyon ABD Doları/km (Kanal Tünel Demiryolu Ağı İlk Fazı) maliyetlerinin yanında oldukça uygundur [13]. Tablo 2'de ülkelerin karşılaştırmalı YHD yapım maliyetleri ortaya konmuştur.

Tablo 2.Yüksek hızlı demiryolları (YHD) yapım maliyetleri [13]

YHD Yapım Maliyetleri

(km başına milyon A.B.D. Doları)

\begin{tabular}{c|c}
\hline Fransa ve İspanya & 10 \\
\hline Belçika ve Almanya & 15 \\
\hline İtalya & 25 \\
\hline Hollanda & 53 \\
\hline Britanya & 74 \\
\hline Tayvan & 37 \\
\hline Güney Kore & 37 \\
\hline
\end{tabular}

Şekil 4'te İngiltere'de Crossrail projesinin mali etkileri görülmektedir. 


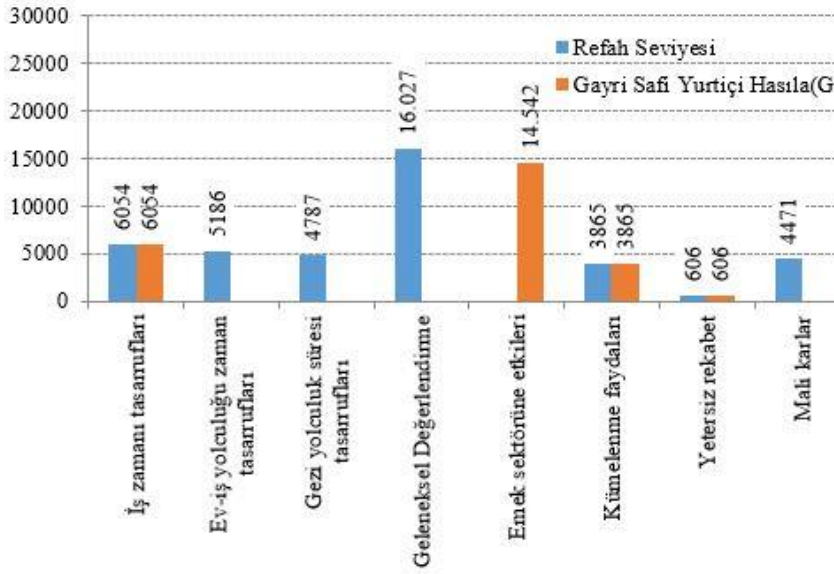

Şekil 4. Crossrail projesinin refah seviyesi ve GSYIH etkileri (milyon ABD doları) [14]

\section{Sonuçlar ve Tartışma}

Yüksek hızlı demiryollarının küresel ölçekte hâlihazır altyapılarda $200 \mathrm{~km} / \mathrm{saat}$ ve üzerindeki hızlarla işletildiği anlaşılmaktadır. 200 $\mathrm{km} / \mathrm{saat}$ 'in üstündeki işletim hızlarına ise çok sayıda ülkede ulaşılabilir iken diğer taraftan da oldukça yüksek hızlar ise test fazında gerçekleştirilmektedir. Olağan YHD işletiminde hız üst limitleri ise ortalama $250-300 \mathrm{~km} / \mathrm{saat}$ 'ler olarak kaydedilmektedir. Söz konusu işletim hızları ise Fransa, Çin, Japonya, Almanya ve İspanya gibi ülkelerde gerçekleştirilmektedir [15].

Demiryolları; çevreci, az yer kaplayan, enerji verimli, petrol bağımlılığı olmayan, alternatif enerji tüketimine imkân sağlayan, karayolu ulaştırma türünün yaklaşık 6 şeritte taşıdığ yolcuyu tek hat bir işletimde taşıyabilen bir ulaştırma türüdür. Çevreye verdiği kayda değer zarar gürültü kaynaklıdır. Diğer çevre kirliliği değerleri ise karayolu ulaştırma türü ve havayolu yolcu taşımacılığının (HYT) yanında çok düşük seviyelerde kalmaktadır. Bundan da öte yüksek hızlı demiryolu (YHD) ulaştırma türünde ise demiryolu ulaştırma türünün haiz olduğu olumlu niteliklerinin hepsinin seviyesi yükselmekte olup buna ilaveten diğer hizmet parametreleri olan konfor, güvenlik ve hız da çok daha üst seviyelerde temin edilebilmektedir. Dolayısı ile yüksek hızlı demiryolu (YHD) ulaştırma türü; üst düzey hizmet parametrelerini sağlayan, çevreci, az yer kaplayan ve havayolu ve karayolu ulaştırma türlerine nazaran daha az maliyetlere sahip bir ulaştırma türüdür. Ayrıca yüksek hızlı demiryollarının (YHD) havayolu yolcu taşımacılığına (HYT) nazaran bir diğer önemli artısı ise terminale erişim ve bekleme, kontrol gibi işlemlerinin çok daha az süre alıyor olmasıdır. Söz konusu durumda, havalimanına erişim, havalimanında uçağa binene kadar ki işlemler, beklemeler ve havalimanından ayrılma süreleri göz önüne alındığında demiryollarının avantajı daha açık olarak görülebilecektir [16].

Bütün bu zaman periyodunda yüksek hızlı tren piyasasında ve hat oluşumunda birçok ülkenin dahli olacak olup doğu Asya'da ise Kore ve Tayvan öncülügünde büyük ölçekli yatırımlar söz konusu olabilecektir. Ekonomik ve mali gereksinimler ile kapasite ihtiyaçları bağlamında Çin'in ilerletilmesini mecburi gördügü bir husus ise kısa vade içerisinde söz konusu hizmetleri yüzölçümünün tamamına genişletme hedefleri bulunmaktadır. Diğer taraftan Çin'den dahi daha hızlı bir şekilde bu söz konusu proje yatırımlarını ivmeli bir şekilde yapması beklenen bir diğer ülke ise İspanya olarak görülmektedir. Bu söz konusu iki ülkenin de yüksek hızlı demiryolu projelerini milli bütünleşme bağlamında hayati gördüğü ve bölgesel ölçeği ile birlikte değerlendirdiği de anlaşılmaktadır [17]. Çok sayıda planlanan yüksek hızlı demiryolu (YHD) ağ1 söz konusu olup bunun nedeni ise bugüne kadar ki süreçte Fransa, Almanya ve Japonya gibi ülkelerde kaydedilen başarılar ve kat edilen yol olmaktadır. Hâlihazırda Tayvan, Çin, Güney Kore gibi uzak Asya ülkelerinde 7.000 kilometreden fazla uzunluktaki bir ağın inşası devam etmekte olup bununla beraber 2.000 kilometre uzunluğundaki yüksek hızlı demiryolu hattının yapımı da İngiltere, Rusya, Fransa ve Almanya'da devam etmektedir [16].

Yüksek hızlı demiryolları (YHD) genel olarak $200 \mathrm{~km} /$ saat'in üzerindeki işletim hızlarına imkân tanıyan altyapılar üzerindeki yüksek hız (YH) sistemleridir. Günümüzde birçok ülkede ortalama $300 \mathrm{~km} /$ saat'teki işletim hızları ile işletilen yüksek hızlı demiryolu (YHD) hattından 
bahsetmek ise mümkündür [17]. Test sürüşlerinde elde edilen hız rekorları ise 500 $\mathrm{km} /$ saat'lerin üzerindedir. Uluslar aras1 Demiryolları Birliği'ne (UIC) göre ise yüksek hızlı demiryolunun (YHD); altyap1, hizmet parametreleri, çeken çekilen araç, işletme ve hız gibi birçok parametreye göre ele alınması gerekmektedir. Yüksek hızlı demiryolları teknik bir yenilik olup, daha hızlı ve etkili bir ulaştırma türü oluşturmak adına 'geleneksek demiryolları' üzerine entegre edilmiş birçok gelişim ile ortaya çıkarılmıştır [18].

\section{Teşekkür}

Akademik çalışmalarımızda emeği geçen hocalarımıza ve arkadaşlarımıza teşekkür ederiz.

\section{Kaynaklar}

[1] Railway Gazette Intern,2009, The Sustainable Railway,http:// archiv.railwaygazette.com/railwaygazette-international.html?tx dc5archive, 63-4. (10.2009)

[2] Kızıltaş, M. Ç., 2014, 'Yükssek Hızlı Demiryolu Politikaları - 1' http://www.ulastirmadunyasi.com/?p=824 (01.11.2014)

[3] 10.Kalkınma Planı Ulaştırma ve Trafik Güvenliği Ö.İ.K. Raporu, 2012, Ankara

[4] Kiziltas, M.C., Altan, M.F., 2017, Evaluation of Intermodal Integration On The Context Of Marmaray and Bosphorus Bridges, IRF Regional Congress, Dubai.

[5] Altan, M.F., Kızıltaş, M.Ç., (2018) Toplu Taşımada Çok Amaçlı Karar Verme ve Metropolitan Bir Alanda Ev-İş Ulaşım Hizmeti Modellemesi, Karaelmas Fen ve Mühendislik Dergisi, ULAKBİM

[6] Ebeling, K., (2005) High-speed railways in Germany, Japan Railway and Transport Review, 40, 36-45.

[7] Watkiss, P.,Jones, R., Rhodes, D., Hardy, A., Handley ve Walker, C., (2001) A Comparative Study of the Environmental Effects of Rail and Short-haul Air Travel. Report for Commission for Integrated Transport, ED50021.

[8] Banister, D.veBerechman, J., (2003) Transport investment and economic development, Routledge.

[9] Anderson, J., 2005, Government ends scoping study on east coast very high speed train network, Johan Anderson MP, Australian Deputy Prime Minister, Minister for Transport andRegionalServices,http://www.ministers.dotars.go v.au/ja/ releases/2002/march/a35_2002.htm (20.06.2005)
[10] Boarnet, M., Crane, R., 2001. Travel by Design: The Influence of Urban Form on Travel. Oxford University Press. Cambridge Systematics Inc., 1998. TCRP Report 35: Economic Impact Analysis of Transit Investment: Guide book for Practitioners. National Academy Press, Washington, D.C.

[11] Cervero, R., 2002. Built environments and mode choice: toward a normative framework. Transportation Research Part D 7 (4), 265-284.

[12] Dodgson, J.,Crompton, R., Bulman, E., Abegg, P., Maunder, S. ve Condorelli, D., (2004) Study of the financing of and public budget contributions to railways, NERA Economic Consulting, Final Report for European Commission, DG Tren, London.

[13] The Transport Politic, Should the U.S. spend \$1 trillion on newinfrastructure?,http://www.thetransportpolitic.co $\mathrm{m} /,(17 / 07 / 2012)$

[14] European Rail Research Advisory Council (ERRAC), (2005) Strategic Rail Research Agenda (SRRA), 2002.

[15] T.C. UDHB 11. UDH Şurası Sektör Raporu.,http://www.ulastirmasurasi.org/tr/main_pag e.html, (11/03/2013)

[16] Woolridge, J.M., 2002. Introductory Econometrics: A Modern Approach. Thomson South-Western, Cincinnati, Ohio.

[17] Chu, Xuehao., 2004. Ridership models at the stop level. National center for transit research. Center for Urban Transportation Research, University of South Florida.

[18] Takagi, R., (2005) High speed railways: the last 10 years, Japan Railway and Transport Review, 40, 4-7. 